\section{Radiochemistry of Chromium and Rhodium}

THe Sub-committee on Radiochemistry, one of several sub-committees working under the Committee of Nuclear Science within the National Academy of Sciences-National Research Council, is responsible for the publication of a series of monographs, each of which collects into one volume pertinent information required for radiochemical work with an individual element. These monographs are revised from time to time to bring the information up to date. Monograph NAS-NS-3007, issued in December 1964 and compiled by J. Pijck (University of Ghent), deals with chromium, and NAS-NS-3008, issued in May 1965 and compiled by J. C. Armstrong (Florida State University) and G. R. Choppin (Hazelton Nuclear Science Corporation, Palo Alto, California), with rhodium (NAS-NS-3007. Radiochemistry of Chromium. By J. Pijck. Pp. v +64.75 cents. NAS-NS-3008: Radiochemistry of Rhodium. By James C. Armstrong, jun., and Gregory R. Choppin. Pp. vi+75. 1 dollar. Washington, D.C.: National Academy of Sciences-National Research Council. Available from the Clearing-house for Federal Scientific and Technical Information, National Bureau of Standards, U.S. Department of Commerce, Springfield, Virginia, 1965). Both monographs are revised and expanded versions of earlier editions. They include reviews of the nuclear and chemical properties of the elements, discussions of methods of sample dissolution and of separation reactions, descriptions of counting techniques and a compilation of radiochemical separation procedures.

\section{Building Economics and Cost Planning}

CERTAIN trends in the building industry, not only in Britain, but also in many other countries, are discernible in modern developments designed to break away from strictly traditional procedures, to establish firmly a more rational code of building economies and a new concept of what has come to be known as 'cost planning'. Contemporary studies of building conditions to-day have conclusively shown that purely technical problems of construction in developed countries are relatively insignificant when compared with problems of cost and labour estimating, budgetary control at all levels, and an urgent need to improve communications throughout the industry. This theme is the subject of a stimulating paper by T. W. Miners entitled "Some Aspects of Building Economics and Cost Planning" (National Building Research Institute, South African Council for Scientific and Industrial Research. CSIR ref. R/Bou 122. Reprinted from South African Architectural Record, 50, No. 2; February 1965). "Cost planning, in its widest sense, may be seen as an attempt to rationalize the cost aspects of a building project, from conception of the idea to build, through the design and construction phases and then finally throughout the life of the building until the period of economic obsolescence has been reached."

Mr. Miners discusses the different types of economic investigations undertaken in co-ordinating national interests, what he calls 'fringe' interests, and those of builders, group interests (such as local authorities), manufacturers, investors, and, last but not least, the interests of the client: ". . . he is the most important person to the industry". In the paragraphs on "Cost Planning and the Design Process", the technique of "cost planning' implies the method used during the design process of kecping the cost of a building project within a predetermined sum; it includes preparation of the 'cost plan', and also the following stages of 'cost checking'. Fundamentally, this seheme of 'cost planning' is envisaged as a bridge between national, design, construction and investment interests; these are closely interrelated and dependent on each other. Some re-organization of the industry along these lines would appear to bo inevitable and this essay makes a strong case for its serious considera- tion. Fully aware of the potential advantages of 'cost planning', the National Building Research Institute has already embarked on a programme of research in this field, including building economics in the wider sense, in collaboration with the Industrial Economics Division of the Council for Scientific and Industrial Research.

\section{Arctic Stratigraphy}

The Triassic Stratigraphy of Svalbard is an example of the major advances being made in many parts of the Arctic from the previous reconnaissance level of geological knowledge (Norsk Polarinstitutt, Skrifter Nr. 135. By S. H. Buchan, A. Challiner, W. B. Harland and J. R. Parker. Pp. 92. Oslo: Norsk Polarinstitutt, $1965.15 \mathrm{kr}$.). It is the result of work carried out by the group directed in the University of Cambridge by W. B. Harland. It contains a review of many scattered earlier publications, but consists mainly of new and detailed observation, much of it elearly presented in diagrammatic measured sections and summarized in a fence diagram. A new scheme of stratigraphical subdivisions is proposed in line with modern international usage. A lengthy "Index to Svalbard Triassic Fossils" includes all published fossil determinations and provisional determinations of the new Cambridge material. Probably the most interesting section for the non-specialist reader is one comparing these Triassic rocks with those of other Arctic areas. This demonstrates the key role of Svalbard in working out the complex pattern of movements between the various Arctic-Atlantic landmasses.

\section{Life Insurance Medical Research Fund of Australia and New Zealand}

APPLICATIONS are invited by the Life Insurance Medical Research Fund of Australia and New Zealand for financial assistance to conduct research broadly related to cardiovascular function and disease. The Fund will award grants-in-aid to non-profit institutions in Australia or New Zealand, equipped with the basic facilities for research, to support a specific programme of fundamental or clinical research under the direction of an experienced full-time investigator. Such grants will be made initially for one to three years. The Fund is also offering research fellowships to university graduates to engage full-time in fundamental or elinical research. Such fellowships will be of two types: (a) fellowships to work in Australia and New Zealand will be granted initially for one year to medical graduates, who need not have previous research experience; $(b)$ travelling fellowships will be granted for a period of two years abroad and a third year in Australia or New Zealand to graduates with at least two years' experience in research. Travelling expenses will be provided for the fellow and his family. Further information and forms of application can be obtained from Dr. H. M. Whyte, medical director, Life Insurance Medical Research Fund of Australia and New Zealand, Box 4134, G.P.O., Sydney, New South Wales. The latest date for receipt of applications is July 1, 1966.

\section{Travelling Research Fellowships to Denmark and Sweden, 1966-67}

Appurcations are invited for the Carlsberg-Wellcome and Wellcome-Swedish travelling research fellowships, 1966-67. The object of these is to encourage working visits, on an exchange basis, between Danish and British, and Swedish and British, investigators in any branches of the natural sciences which have a bearing on human and animal medicine. Ono of each fellowship is awarded annually to a graduate from the United Kingdom for $a$ year's work in the exchange country, and one Swedish and one Danish candidate annually may work in the United Kingdom. The stipend may range from $£ 1,000$ to $£ 2,000$ per annum; travelling and some incidental 